\title{
Facile Preparation of Allylzinc Species from Allyl Bromides and Unactivated Zinc Induced by a Catalytic Amount of Aluminum Chloride and Their Reactions with Carbonyl Compounds and Acetals
}

\author{
Hatsuo MaEDa, Kazushige SHONo, and Hidenobu OHMORI* \\ Faculty of Pharmaceutical Sciences, Osaka University, 1-6 Yamadaoka, Suita, Osaka 565, Japan. \\ Received March 25, 1994; accepted May 13, 1994
}

The effects of Lewis acids $\left(\mathrm{ZnCl}_{2}, \mathrm{AlCl}_{3}, \mathrm{BF}_{3}\right.$, and $\left.\mathrm{TiCl}_{4}\right)$ on the generation of allylzinc species from allyl bromide and unactivated zinc powder in dry tetrahydrofuran (THF) were examined by trapping the organozinc compound with benzaldehyde, that is, Grignard-type allylation of the aldehyde. Among the Lewis acids employed, $\mathrm{AlCl}_{3}$ was found to be the promoter of choice. The allylzinc species preformed in the presence of a catalytic amount of $\mathrm{AlCl}_{3}$ effectively allylated carbonyl compounds. Various aromatic and aliphatic aldehydes as well as ketones were converted into homoallylic alcohols in good to excellent yields. Under the reaction conditions employed, ester, hydroxy, acetal, and aromatic nitro and halide groups were tolerated. In the case of $\alpha, \beta$-unsaturated carbonyl compounds, selective 1,2-addition was observed. Substituted allyl bromides such as prenyl, crotyl, cinnamyl, and 2-cyclohexenyl bromides were smoothly converted to the corresponding allylzinc compounds, which reacted with carbonyl compounds to give substituted homoallylic alcohols in excellent yields. The diastereoselectivity in crotylation, cinnamylation, and 2-cyclohexenylation depended upon the structures of both the organic metals and the electrophiles. The origin of the observed selectivity is discussed. The allylation of dimethyl and cyclic acetals accompanied with carbon-oxygen bond cleavage also proceeded in excellent yields provided that two equivalents of $\mathrm{AlCl}_{3}$ was present.

Keywords allylzinc species; aluminum chloride; allylation; carbonyl compound; acetal; allyl bromide

Allylation of carbonyl compounds by allyl bromide and unactivated zinc is known to be effectively performed in tetrahydrofuran (THF)- or solid organic phase-saturated aqueous $\mathrm{NH}_{4} \mathrm{Cl}^{1,2)}$ Recently, it was found independently by us and other groups that pyridinium ions in $\mathrm{CH}_{3} \mathrm{CN}^{3)}$ or in aqueous $\mathrm{THF}^{2,4)}$ can also promote the allylation. Although these systems are useful for the activation of the metal surface in the Barbier-type allylation, they seem inapplicable to reactions using zinc metal and other organic halides, including the Reformatsky reaction, probably due to the presence of water. Accordingly, it seemed worthwhile to search for a general promoter of the electron transfer from unactivated zinc to organic halides under anhydrous conditions, efficiently generating organozinc compounds. We have investigated whether a Lewis acid can meet this requirement, as proton acids such as $\mathrm{NH}_{4}^{+}$and pyridinium ions do under the aqueous conditions mentioned above. In this paper, we wish to show that $\mathrm{AlCl}_{3}$ in dry THF is a promising promoter for allylation of carbonyl compounds and acetals.

\section{Results and Discussion}

The effects of $\mathrm{AlCl}_{3}$ upon the formation of allylzinc species from allyl bromide and unactivated zinc powder were first examined by trapping the organozinc compound with benzaldehyde (1a), that is, by a Grignard-type allylation of 1a (Chart 1). The reaction was carried out as follows: a mixture of zinc powder and allyl bromide (2a) in dry THF with or without $\mathrm{AlCl}_{3}$ was stirred for

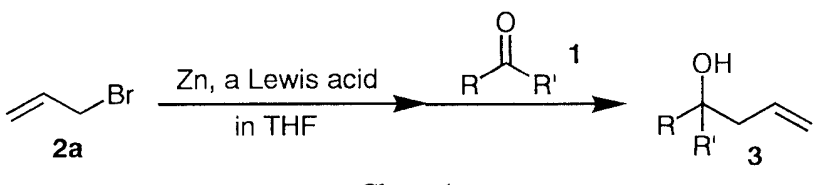

Chart 1
$5 \mathrm{~min}$ at room temperature, $\mathbf{1 a}$ was added to the suspension, and the resulting mixture was stirred for another $10 \mathrm{~min}$. The reaction was quenched by adding $10 \%$ aqueous $\mathrm{HCl}$, and the homoallyl alcohol 3a was isolated by usual work-up. The results are summarized in Table I.

When a suspension of zinc powder and $\mathbf{2 a}$ in THF without any Lewis acid was stirred at room temperature, the metal appeared not to be consumed at all, although the addition of $\mathbf{1 a}$ to the suspension gave the desired product 3a in $42 \%$ yield, probably through a Barbier-type reaction (run 1). Under these conditions it took $12 \mathrm{~h}$ to obtain 3a in a satisfactory yield (as much as 75\%), but a small amount of $1 \mathrm{a}$ still remained. In the presence of $\mathrm{AlCl}_{3}$ in an amount equal to that of zinc powder, the metal surface was activated to cause a rapid reaction between the metal and $\mathbf{2 a}$, and the metal appeared to be totally consumed within $10 \mathrm{~min}$. Upon addition of $\mathbf{1 a}$ to the mixture, the allylation smoothly proceeded, 1a was completely consumed within $10 \mathrm{~min}$, and $\mathbf{3 a}$ was isolated in an excellent yield (run 2). Furthermore, a catalytic

TABLE I. Effects of a Lewis Acid on Grignard-Type Allylation of Benzaldehyde (1a) by Allyl Bromide (2a) and Zinc Powder in THF ${ }^{a}$

\begin{tabular}{cccc}
\hline \hline Run & Lewis acid & $\begin{array}{c}\text { Amount of a } \\
\text { Lewis acid (eq) })^{b)}\end{array}$ & $\begin{array}{c}\text { Yield of 3a } \\
(\%)^{c)}\end{array}$ \\
\hline 1 & None & - & 42 \\
2 & $\mathrm{AlCl}_{3}$ & 1.2 & 87 \\
3 & $\mathrm{AlCl}_{3}$ & 0.1 & 92 \\
4 & $\mathrm{ZnCl}_{2}$ & 0.1 & 56 \\
5 & $\mathrm{BF}_{3}{ }^{2}$ & 0.1 & 52 \\
6 & $\mathrm{TiCl}_{4}$ & 0.1 & 88 \\
\hline
\end{tabular}

a) The mixture of $\mathbf{2 a}$ and zinc powder with or without a Lewis acid in THF was stirred for $5 \mathrm{~min}$. To the suspension, 1a was added and the resulting mixture was stirred for another $10 \mathrm{~min}$. b) With respect to 1a. c) Isolated yield. d) A solution of its diethyl etherate was used. 
TABLE II. Grignard-Type Allylation of Carbonyl Compounds (1) by Allyl Bromide (2a) and Zinc Powder in the Presence of a Catalytic Amount of $\mathrm{AlCl}_{3}$ in THF

\begin{tabular}{|c|c|c|c|c|c|}
\hline \multirow{2}{*}{ Run } & & \multicolumn{2}{|l|}{1} & \multirow{2}{*}{$\begin{array}{l}\text { Time }^{a)} \\
(\min )\end{array}$} & \multirow{2}{*}{$\begin{array}{c}\text { Yield of } 3 \\
(\%)^{b)}\end{array}$} \\
\hline & & $\mathrm{R}$ & $\mathrm{R}^{\prime}$ & & \\
\hline 1 & $\mathbf{a}$ & $\mathrm{Ph}-$ & $\mathrm{H}$ & 10 & 92 \\
\hline 2 & $\mathbf{b}$ & $p-\mathrm{Cl}-\mathrm{Ph}-$ & $\mathrm{H}$ & 20 & 92 \\
\hline 3 & c & $p-\mathrm{CH}_{3} \mathrm{O}-\mathrm{Ph}-$ & $\mathrm{H}$ & 10 & 87 \\
\hline 4 & d & $o-\mathrm{HO}-\mathrm{Ph}-$ & $\mathbf{H}$ & 60 & $67(88)^{c)}$ \\
\hline 5 & $\mathbf{e}$ & $p-\mathrm{O}_{2} \mathrm{~N}-\mathrm{Ph}-$ & $\mathrm{H}$ & 30 & 82 \\
\hline 6 & f & $p-\mathrm{CH}_{3} \mathrm{O}_{2} \mathrm{C}-\mathrm{Ph}-$ & $\mathbf{H}$ & 10 & 96 \\
\hline 7 & $\mathbf{g}$ & $\mathrm{PhCH}_{2} \mathrm{CH}_{2}-$ & $\mathrm{H}$ & 10 & 91 \\
\hline 8 & h & cyclo- $\mathrm{C}_{6} \mathrm{H}_{11^{-}}$ & $\mathrm{H}$ & 20 & 78 \\
\hline 10 & $\mathbf{i}$ & $\mathrm{PhCH}\left(\mathrm{CH}_{3}\right)-$ & $\mathrm{H}$ & 10 & $91(79: 21)^{d)}$ \\
\hline 11 & $\mathbf{j}$ & $\mathrm{PhCH}=\mathrm{CH}-$ & $\mathrm{H}$ & 10 & 83 \\
\hline 12 & $\mathbf{k}$ & $\mathrm{Ph}-$ & $\mathrm{CH}_{3}-$ & 30 & 78 \\
\hline 13 & 1 & $-\mathrm{CH}_{2} \mathrm{CH}_{2} \mathrm{C}($ tert $-\mathrm{Bu}) \mathrm{CH}_{2}$ & $\mathrm{CH}_{2}-$ & 10 & $87(85: 15)^{e)}$ \\
\hline 14 & m & $-\mathrm{CH}=\mathrm{CHCH}_{2} \mathrm{CH}_{2} \mathrm{CH}_{2}-$ & & 10 & 74 \\
\hline 15 & $\mathbf{n}$ & $\left(\mathrm{CH}_{3} \mathrm{O}\right)_{2} \mathrm{CH}-$ & $\mathrm{CH}_{3-}^{-}$ & 20 & 71 \\
\hline 16 & $\mathbf{o}$ & $\mathrm{HOCH}_{2} \mathrm{CH}_{2}-$ & $\mathrm{CH}_{3}-$ & 40 & $49(67)^{c)}$ \\
\hline 17 & $\mathbf{p}$ & $\mathrm{CH}_{3} \mathrm{O}_{2} \mathrm{CCH}_{2}^{-}$ & $\mathrm{CH}_{3}-$ & 10 & 77 \\
\hline
\end{tabular}

a) After the addition of $\mathbf{1}$ to a mixture of $2 \mathbf{a}$, zinc powder, and a catalytic amount of $\mathrm{AlCl}_{3}$ in THF. b) Isolated yield. c) Isolated yield obtained when 2 eq of $2 \mathrm{a}$ and zinc powder with respect to 1 were used. d) The ratio of Cram/anti-Cram selectivity in the formation of $2 \mathbf{i}$. e) The ratio between axial and equatorial homoallylic alcohols.

amount of $\mathrm{AlCl}_{3}(0.1$ eq against 1a) was found to be sufficient for the formation of the organometallic species, allowing effective transformation of $\mathbf{1 a}$ to $\mathbf{3 a}$ (run 3).

The effects of Lewis acids other than $\mathrm{AlCl}_{3}$ were also examined. The presence of $\mathrm{ZnCl}_{2}, \mathrm{BF}_{3}$, and $\mathrm{TiCl}_{4}$ improved the generation of allyl zinc species, giving better results for the transformation than that in the absence of a Lewis acid, and $\mathrm{TiCl}_{4}$ turned out to be an excellent promoter for the reaction as well as $\mathrm{AlCl}_{3}$ (runs 4-6). Nevertheless, $\mathrm{AlCl}_{3}$ is regarded as a better additive than $\mathrm{TiCl}_{4}$ for the allylation, taking easiness of handling into consideration.

The Grignard-type allylation with zinc powder and 2a in the presence of a catalytic amount of $\mathrm{AlCl}_{3}$ was applied to various carbonyl compounds. As is apparent from the results in Table II, the present method is quite general in that it can be applied to the preparation of homoallylic alcohols 3 containing various functional groups. An aromatic nitro group, which had been considered liable to reduction under the reaction conditions, caused no problem in the allylation (run 5), and highly chemoselective allylation of aldehydes and ketones over esters was achieved (runs 6, 17). The allylation of $\mathbf{1 d}$ and $\mathbf{1 0}$ was effectively performed in reasonable yields by the preformed allyl zinc species without protecting the hydroxy groups, and the yields were improved by utilizing 2 eq of $\mathbf{2 a}$ and zinc powder (runs 4,16 ), which matches the results in aqueous media. The result in run 15 shows that the present method is useful for the allylation of an acid-sensitive carbonyl compound such as $\mathbf{1 n}$. Furthermore, the method can be applied to the preparation of $\mathbf{3 p}$ from the enolizable ketone 1p (run 17). When $\alpha, \beta$-unsaturated carbonyl compounds $\mathbf{1 j}$ and $\mathbf{1 m}$ were subjected to the reaction, 1,2-addition was selectively achieved (runs 11, 14).

The results in runs 10 and 13 show the stereoselectivity
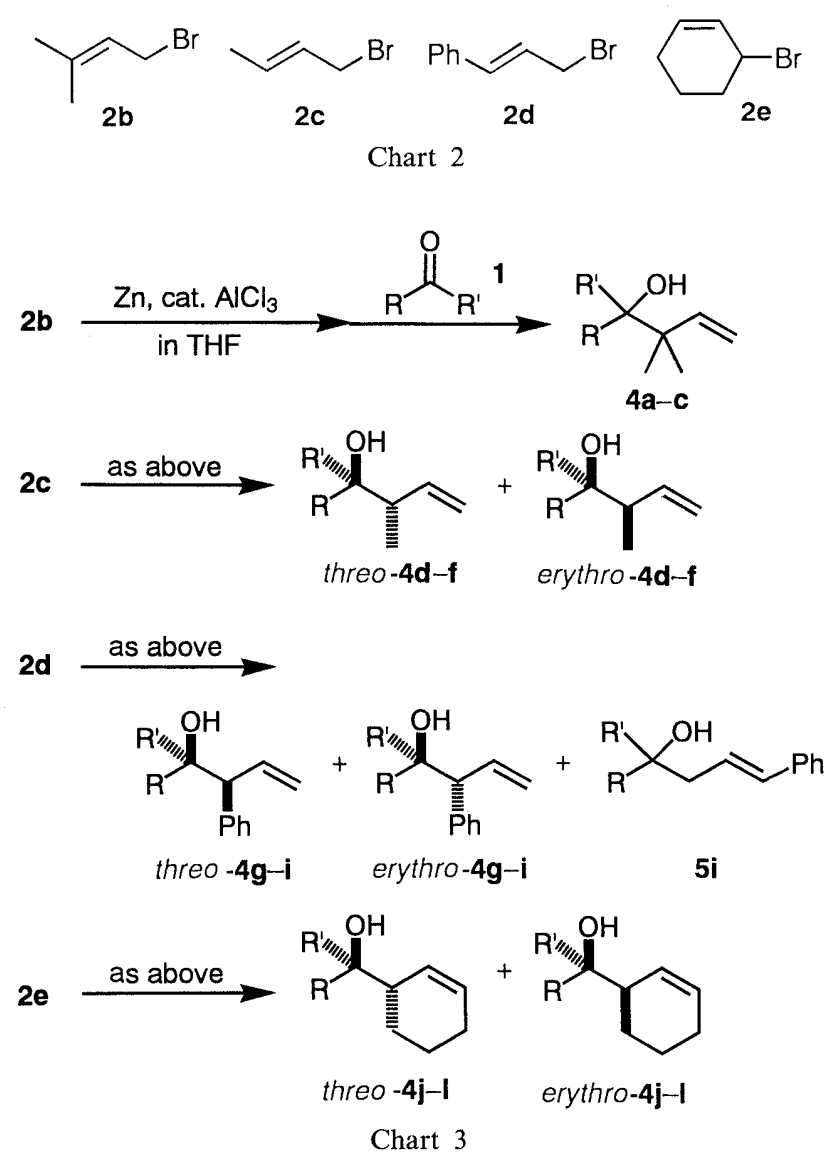

in the present allylation. Cram-selectivity was observed in the reaction of $\mathbf{1 i}$ to the same extent as in an aqueous solvent system. ${ }^{2)}$ A homoallylic alcohol 31 was obtained from 4-tert-butylcyclohexanone (11) as a mixture of axial- and equatorial-alcohols in the ratio of $85: 15$, which is identical with the result observed in the reaction of 11 with allylzinc bromide preformed by reducing allyl phenyl ether with naphthalide radical anion, ${ }^{5)}$ and higher than that from the Barbier-type allylation in an aqueous solvent system. ${ }^{2)}$

The application of the present reaction to substituted allyl bromides was also explored: prenyl, crotyl, cinnamyl, and 2-cyclohexenyl bromides (2b-e) (Chart 2) were employed.

As shown in Chart 3 and Table III, the present method seems to have no restriction with respect to the structure of allyl bromides, in contrast to the allylation in aqueous THF, where $\mathbf{2 d}$ and $\mathbf{2 e}$ could not enter the reaction course. ${ }^{1 c)}$ Thus, all allyl bromides examined here were smoothly transformed into the corresponding allylzinc species, which reacted with benzaldehyde (1a), 3-phenylpropionaldehyde $(\mathbf{1 g})$, and acetophenone $(\mathbf{1 k})$ to give $\mathbf{4 a}-\mathbf{l}$ in fair to good yields. In all cases except for the cinnamylation of $\mathbf{1 k}$, the allylic group was linked at the more substituted carbon, that is, at the $\gamma$-carbon of allyl bromides, in a highly regioselective manner, although $\mathrm{AlCl}_{3}$ has been reported to induce $\alpha$-addition of allyl Grignard reagents to carbonyl compounds. ${ }^{6)}$ When $1 k$ was subjected to the reaction with cinnamylzinc species, the corresponding $\alpha$-adduct $\mathbf{5 i}$ was obtained in $22 \%$ yield as well as the $\gamma$-adduct $4 \mathbf{i}$. The formation of the $\alpha$-adduct can 
TABLE III. Grignard-Type Allylation of Carbonyl Compounds (1) by Substituted Allyl Bromides (2c-e) and Zinc Powder in the Presence of a Catalytic Amount of $\mathrm{AlCl}_{3}$ in THF

\begin{tabular}{rcccccc}
\hline \hline Run & $\begin{array}{c}\text { Carbonyl } \\
\text { compound }\end{array}$ & $\begin{array}{c}\text { Allyl } \\
\text { bromide }\end{array}$ & $\begin{array}{c}\text { Time }^{a)} \\
(\mathrm{min})\end{array}$ & Product & $\begin{array}{c}\text { Yield }^{\boldsymbol{b})} \\
(\%)\end{array}$ & $\begin{array}{c}\text { Ratio }^{(\boldsymbol{c})} \text { of } \\
\text { threo/erythro }^{(}\end{array}$ \\
\hline 1 & $\mathbf{1 a}$ & $\mathbf{2 b}$ & 10 & $\mathbf{4 a}$ & 81 & - \\
2 & $\mathbf{1 g}$ & $\mathbf{2 b}$ & 10 & $\mathbf{4 b}$ & 79 & - \\
3 & $\mathbf{1 k}$ & $\mathbf{2 b}$ & 20 & $\mathbf{4 c}$ & 69 & - \\
4 & $\mathbf{1 a}$ & $\mathbf{2 c}$ & 10 & $\mathbf{4 d}$ & 90 & $55: 45$ \\
5 & $\mathbf{1 g}$ & $\mathbf{2 c}$ & 20 & $\mathbf{4 e}$ & 93 & $54: 46$ \\
6 & $\mathbf{1 k}$ & $\mathbf{2 c}$ & 15 & $\mathbf{4 f}$ & 92 & $65: 35$ \\
7 & $\mathbf{1 a}$ & $\mathbf{2 d}$ & 10 & $\mathbf{4 g}$ & $100^{d)}$ & $14: 86$ \\
8 & $\mathbf{1 g}$ & $\mathbf{2 d}$ & 20 & $\mathbf{4 h}$ & $90^{d)}$ & $27: 73$ \\
9 & $\mathbf{1 k}$ & $\mathbf{2 d}$ & 20 & $\mathbf{4 i}$ & $78^{d, e)}$ & $17: 83$ \\
10 & $\mathbf{1 a}$ & $\mathbf{2 e}$ & 10 & $\mathbf{4 j}$ & $98^{d)}$ & $11: 89$ \\
11 & $\mathbf{1 g}$ & $\mathbf{2 e}$ & 10 & $\mathbf{4 k}$ & $99^{d)}$ & $56: 44$ \\
12 & $\mathbf{1 k}$ & $\mathbf{2 e}$ & 15 & $\mathbf{4 l}$ & $99^{d)}$ & $3: 97$ \\
\hline
\end{tabular}

a) After the addition of $\mathbf{1}$ to a mixture of an allyl bromide, zinc powder, and a catalytic amount of $\mathrm{AlCl}_{3}$ in THF. b) Isolated yield. c) Determined by GLC $(\mathbf{4 d}-\mathbf{f}, \mathbf{4 i}, \mathbf{4 k}),{ }^{1} \mathrm{H}-\mathrm{NMR}(\mathbf{4 g}, \mathbf{4 j})$, isolation (4h), and $\left.{ }^{13} \mathrm{C}-\mathrm{NMR}(\mathbf{4 1}), \quad d\right)$ Two eq of 2 and zinc powder with respect to 1 were used. e) An $\alpha$-adduct $5 \mathrm{i}$ was obtained in $22 \%$ yield.

be ascribed simply to the steric hindrance between the phenyl group in the cinnamyl moiety and the ketone encountered in the $y$-addition.

Table III also shows the diastereoselectivities in the allylation with $\mathbf{2 c}, \mathbf{2 d}$, and $2 \mathbf{2 e}$. Threo and erythro refer to the relative configurations of adjacent alcoholic and allylic carbons in 4 (Chart 3), based on the nomenclature proposed by Noyori et al. ${ }^{7)}$ The stereochemical assignments were made by comparison of the ${ }^{1} \mathrm{H}-\mathrm{NMR}$ spectra with those of the same $\left(\mathbf{4 d},{ }^{8)} 4 \mathbf{e},{ }^{8)} \mathbf{4 f},{ }^{9)} \mathbf{4 g},{ }^{10)} 4 \mathbf{h},{ }^{11)}\right.$ and $\mathbf{4} \mathbf{j}^{12)}$ ) or similar compounds $\left(\mathbf{4} \mathbf{k}^{12)}\right)$. Tentative assignments for $\mathbf{4 i}$ and $\mathbf{4 l}$ are based on the assumption that the topology of the transition state is analogous to that of the cinnamylation and the 2-cyclohexenylation of $\mathbf{1 a}$, and on a comparison of the retention time of each isomer observed on GLC analyses of $\mathbf{4 g}$ and $\mathbf{4 i}$.

In general, a cyclic six-membered transition state is invoked to explain the stereochemical outcome in the reaction of carbonyl compounds with crotylmetal compounds, including the zinc derivatives, and hence the threo/erythro ratio should reflect the $E / Z$ ratio of the crotyl unit in the organic metals. ${ }^{13)}$ Thus, crotylzinc species, which tend to undergo a rapid $E / Z$ isomerization even at low temperatures, ${ }^{13)}$ are not expected to be useful for stereoselective synthesis. As expected, only marginal threo-selectivity was observed in the crotylation of $\mathbf{1 a}$ and $\mathbf{1 g}$ (runs 4, 5). A slight increase in selectivity for $\mathbf{1 k}$ (run 6 ) can be ascribed to the tendency of the $E$-crotylzinc species to be more reactive than its $Z$-isomer, which will be emphasized in the crotylation of a weaker electrophile. In other words, the $E$-crotylzinc species will react with $\mathbf{1 k}$ faster than the $Z$-isomer, leading into better threoselectivity via a conventional transition state, whereas both of the zinc species seem to add to more-reactive carbonyl compounds $1 \mathrm{a}$ and $1 \mathrm{~g}$ at almost the same rates, and produce 4 as a mixture of nearly $1: 1$ isomer ratio.

The fact that cinnamylation of $1 \mathbf{a}, 1 \mathbf{1 g}$, and $1 \mathbf{k}$ was achieved with good erythro-selectivity (runs 7-9) seems reasonable as judged from the expectation that $E$ -

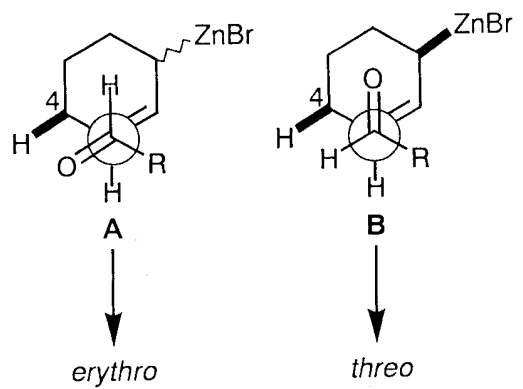

Chart 4

cinnamylzinc species can not isomerize into the $Z$-isomer with a large allylic strain.

When the reactions of 2-cyclohexenylzinc species with $1 \mathbf{a}$ and $1 \mathbf{k}$ were carried out, high erythro-selectivities of 78 and $94 \%$ ds were realized, respectively (runs 10, 12). Unexpectedly, the selectivity was reversed in the reaction with an aliphatic aldehyde $\mathbf{1 g}$, and threo-4k was obtained in slight preference to the erythro isomer (run 11). Thus, the diastereo-selectivity in the reaction is suggested to be determined by the identity of the carbonyl compounds, that is, whether $\mathbf{1}$ is aromatic or aliphatic. For a possible transition state in the cyclohexenylation, the two arrangements depicted in Chart 4 can be considered on the basis of a model study, in which the steric interaction between $\mathrm{R}$ and the proton at $\mathrm{C} 4$ was minimized. The observed stereochemical results indicate that the antiperiplanar arrangement $\mathrm{A}$ is favored for the addition of 2-cyclohexenylzinc species to aromatic carbonyl compounds $1 \mathbf{a}$ and $1 \mathbf{k}$ while in the cyclohexenylation of the aliphatic aldehyde $\mathbf{1 g}$, the synclinal one $\mathbf{B}$ is slightly predominant over $\mathrm{A}$. The change in the predominance between the two presumed arrangements can be explained as follows. In the case of aromatic carbonyl compounds, the electron density of the carbonyl oxygen should be lower than that in the aliphatic one, which will reduce the chelating ability of the former oxygen atom to the metal center, resulting in the predominant formation of erythro-products via A. On the contrary, the carbonyl oxygen atom in the aliphatic aldehyde will be allowed to interact with the metal and the arrangement $B$ is now slightly favored, inducing the small threo-selectivity. Thus, not a steric effect but an electronic effect seems to govern the stereochemical selectivity in the present 2-cyclohexenylation.

A totally opposite selectivity has been noted in the reaction of 2-cyclohexenylstannanes, in which a slight threo-selectivity was observed for 1a, while alkanals gave the corresponding homoallyl alcohols with high erythroselectivity. ${ }^{12)}$ Accordingly, the present method and the stannane method are complementary for highly erythroselective cyclohexenylation.

Since it is well known that the reaction of acetals (6) with organometallic reagents can be promoted by Lewis acids, ${ }^{14)}$ the present method was also applied to the allylation of acetals accompanied with nucleophilic $\mathrm{C}-\mathrm{O}$ bond cleavage (Chart 5). The results are summarized in Table IV.

When benzaldehyde dimethyl acetal (6a) was subjected to the reaction under the same conditions as used for $\mathbf{1}$, 


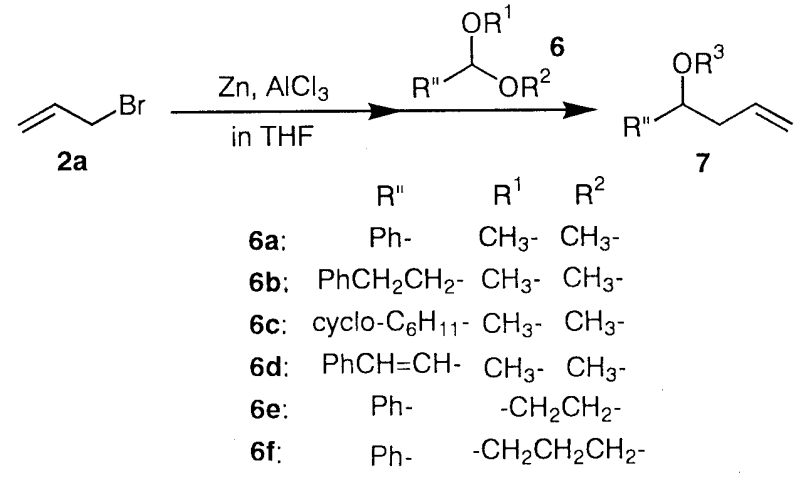

Chart 5

TABLE IV. Grignard-Type Allylation of Acetals (6) by Allyl Bromide (2a) and Zinc Powder in the Presence of $\mathrm{AlCl}_{3}$ in $\mathrm{THF}^{a}$ )

\begin{tabular}{|c|c|c|c|c|c|}
\hline \multirow{2}{*}{ Run } & & \multicolumn{2}{|c|}{7} & \multirow{2}{*}{$\begin{array}{c}\mathrm{AlCl}_{3} \\
(\mathrm{eq})^{b)}\end{array}$} & \multirow{2}{*}{$\begin{array}{l}\text { Yield } \\
(\%)^{c}\end{array}$} \\
\hline & & $\mathrm{R}^{\prime \prime}$ & $\mathrm{R}^{3}$ & & \\
\hline 1 & $\mathbf{a}$ & $\mathrm{Ph}_{-}$ & $\mathrm{CH}_{3-}$ & 0.1 & 0 \\
\hline 2 & $\mathbf{a}$ & $\mathrm{Ph}-$ & $\mathrm{CH}_{3}$ & 1.2 & 78 \\
\hline 3 & $\mathbf{a}$ & $\mathrm{Ph}$ & $\mathrm{CH}_{3-}$ & 2.0 & 89 \\
\hline 4 & b & $\mathrm{PhCH}_{2} \mathrm{CH}_{2}-$ & $\mathrm{CH}_{3}-$ & 2.0 & 77 \\
\hline 5 & c & cyclo- $\mathrm{C}_{6} \mathrm{H}_{11}$ & $\mathrm{CH}_{3}$ & 2.0 & 85 \\
\hline 6 & d & $\mathrm{PhCH}=\mathrm{CH}-$ & $\mathrm{CH}_{3}-$ & 2.0 & 95 \\
\hline 7 & $\mathbf{e}$ & $\mathrm{Ph}$ & $\mathrm{HO}\left(\mathrm{CH}_{2}\right)_{2-}$ & 2.0 & 95 \\
\hline 8 & f & $\mathrm{Ph}_{-}$ & $\mathrm{HO}\left(\mathrm{CH}_{2}\right)_{3}-$ & 2.0 & 94 \\
\hline
\end{tabular}

a) After an acetal was added to the suspension of allyl bromide, zinc, and $\mathrm{AlCl}$ in $\mathrm{THF}$, the resulting mixture was stirred at room temperature for $18 \mathrm{~h}$. $b$ ) With respect to $6 . c$ ) Isolated yield.

the desired product was not obtained, as expected from the result in run 15 of Table II (run 1). With an increased amount of $\mathrm{AlCl}_{3}$, however, the formation of $7 \boldsymbol{a}$ was stimulated (run 2), and the addition of 2 eq of $\mathrm{AlCl}_{3}$ eventually gave a satisfactory result (run 3 ). Under the conditions utilized in run 3 , dimethyl acetals derived from aliphatic aldehydes were converted to the corresponding products 7 in fair yields (runs 4,5 ). In the case of $\alpha, \beta$-unsaturated dimethyl acetal $\mathbf{6 d}$, the 1,2 -addition product was obtained exclusively and 1,4-addition was not recognized. Cyclic acetals $\mathbf{6 e}$ and $\mathbf{6 f}$ reacted smoothly as well, giving 7e and $7 \mathbf{f}$, respectively, in excellent yields.

Since the present method is not a Barbier-type allylation, it is believed that the allylzinc species is responsible for the successful reaction, instead of a free radical pair on the metallic surface as proposed in the Barbier-type reaction. ${ }^{1 c, 15)}$ The role of $\mathrm{AlCl}_{3}$ in the reaction course is considered to be as follows: (1) the Lewis acid enhances the electron-accepting ability of allyl bromides from zinc powder by coordinating the bromides as seen in FriedelCrafts reactions; (2) the initial generation of allylzinc species through process (1) can give a clean surface on the metal; (3) the activated surface leads to the rapid consumption of the bromides to form organozinc compounds. The above hypothesis is supported by the observation that the addition of allyl bromide to a suspension of zinc in THF in the presence of a catalytic amount of $\mathrm{AlCl}_{3}$ caused an exothermic reaction; while mixing zinc powder with the Lewis acid in THF did not induce any change, that is, the formation of active aluminum metal was not recognized even in the presence of excess $\mathrm{AlCl}_{3}$.

In summary, the present results show that a catalytic amount of $\mathrm{AlCl}_{3}$ can promote the formation of allylzinc species from allyl bromide and unactivated zinc under dry conditions. By using the allylzinc species, allylation of various carbonyl compounds is effectively performed and nucleophilic cleavage of acetals is achieved in the presence of an additional amount of the Lewis acid. Further studies on applying the present method to other organic halides, such as propargyl bromides and $\alpha$-bromo acetate, are in progress.

\section{Experimental}

Infrared (IR) spectra were taken on a JASCO A-202 spectrometer. ${ }^{1} \mathrm{H}$ - and ${ }^{13} \mathrm{C}$-NMR spectra were obtained at 270 and $68 \mathrm{MHz}$ on JEOL EX-270 spectrometers, respectively, in $\mathrm{CDCl}_{3}$ with tetramethylsilane (TMS) as an internal standard. For column chromatography, $\mathrm{SiO}_{2}$ (Wakogel C-200) was used.

Materials All chemicals were of reagent grade, and were used without further purification. THF was distilled from $\mathrm{K}$ and benzophenone under an $\mathrm{N}_{2}$ atmosphere prior to use.

General Procedure for the Preparation of Homoallylic Alcohols (3, 4) An allyl bromide ( $2 \mathrm{a}-\mathbf{e})$ (3.6 or $6 \mathrm{mmol})$ was added to a suspension of zinc $(3.6$ or $6 \mathrm{mmol})$ and $\mathrm{AlCl}_{3}(0.3 \mathrm{mmol})$ in THF $(10 \mathrm{ml})$ at room temperature under an $\mathrm{N}_{2}$ atmosphere, causing an exothermic reaction. The resulting mixture was stirred for another $5 \mathrm{~min}$, then a solution of $1(3.0 \mathrm{mmol})$ in THF $(5 \mathrm{ml})$ was added to it. The mixture was allowed to stand under stirring until 1 was totally consumed, and then it was poured into $10 \% \mathrm{HCl}$ or saturated $\mathrm{NH}_{4} \mathrm{Cl}(50 \mathrm{ml})$. The whole was extracted with ether $(50 \mathrm{ml} \times 3)$. The combined organic layers were washed with brine, dried over $\mathrm{MgSO}_{4}$, and evaporated in vacuo. The residue was subjected to column chromatography $\left(\mathrm{SiO}_{2}\right.$; hexane-ethyl acetate) to afford a pure homoallylic alcohol. The ${ }^{1} \mathrm{H}-\mathrm{NMR}$ and IR

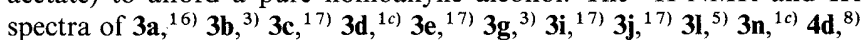
$4 \mathbf{4 e},{ }^{8)} \mathbf{4 f},{ }^{9)} \mathbf{4 g},{ }^{11)}$ and $4 \mathrm{j},{ }^{12)}$ coincided with those in the literature. All other products gave satisfactory IR, ${ }^{1} \mathrm{H}-\mathrm{NMR}$, and ${ }^{13} \mathrm{C}-\mathrm{NMR}$ spectra (see below).

Methyl (1-Hydroxy-3-buten-4-yl)benzoate (3f) A colorless oil. IR (neat): $3400,1725,1645 \mathrm{~cm}^{-1} .{ }^{1} \mathrm{H}-\mathrm{NMR} \delta: 8.02(2 \mathrm{H}, \mathrm{d}, J=8.4 \mathrm{~Hz}), 7.43$ $(2 \mathrm{H}, \mathrm{d}, J=8.4 \mathrm{~Hz}), 5.87-5.72(1 \mathrm{H}, \mathrm{m}), 5.20-5.15(2 \mathrm{H}, \mathrm{m}), 4.81(1 \mathrm{H}$, dd, $J=7.6,4.9 \mathrm{~Hz}), 3.92(3 \mathrm{H}, \mathrm{s}), 2.58-2.41(2 \mathrm{H}, \mathrm{m}) \cdot{ }^{13} \mathrm{C}-\mathrm{NMR} \delta: 166.9$ (s), 149.0 (s), 133.8 (d), 129.7 (d), 129.2 (s), 125.7 (d), 119.0 (t), 72.7 (d), $52.1(\mathrm{q}), 43.8(\mathrm{t})$

1-Cyclohexyl-3-buten-1-ol (3h) A colorless oil. IR (neat): 3380 , $1645 \mathrm{~cm}^{-1}$. ${ }^{1} \mathrm{H}-\mathrm{NMR} \delta: 5.92-5.77(1 \mathrm{H}, \mathrm{m}), 5.18-5.07(2 \mathrm{H}, \mathrm{m})$, $3.43-3.36(1 \mathrm{H}, \mathrm{m}), 2.38-2.29(1 \mathrm{H}, \mathrm{m}), 2.18-2.06(1 \mathrm{H}, \mathrm{m}), 1.88-0.99$ $(11 \mathrm{H}, \mathrm{m}) .{ }^{13} \mathrm{C}-\mathrm{NMR} \delta: 135.5(\mathrm{~d}), 117.9(\mathrm{t}), 74.7(\mathrm{~d}), 43.1(\mathrm{~d}), 38.8(\mathrm{t})$, $29.1(\mathrm{t}), 28.1(\mathrm{t}), 26.5(\mathrm{t}), 26.3(\mathrm{t}), 26.1(\mathrm{t})$.

2-Phenyl-4-penten-2-ol (3k) A colorless oil. IR (neat): $3400 \mathrm{~cm}^{-1}$. ${ }^{1} \mathrm{H}-\mathrm{NMR} \delta: 7.46-7.21(5 \mathrm{H}, \mathrm{m}), 5.70-5.54(1 \mathrm{H}, \mathrm{m}), 5.16-5.10(2 \mathrm{H}$, $\mathrm{m}), 2.69(1 \mathrm{H}, \mathrm{dd}, J=13.7,6.6 \mathrm{~Hz}), 2.50(1 \mathrm{H}, \mathrm{dd}, J=13.7$ and $8.4 \mathrm{~Hz})$, $1.98\left(1 \mathrm{H}\right.$, br s) $, 1.55(3 \mathrm{H}, \mathrm{s}) .{ }^{13} \mathrm{C}-\mathrm{NMR} \delta: 147.9(\mathrm{~s}), 134.0(\mathrm{~d}), 128.5(\mathrm{~d})$, 127.0 (d), 125.0 (d), 119.8 (t), 73.9 (s), 48.8 (t), 30.2 (q).

(2-Propen-1-yl)-2-cyclohexen-1-ol (3m) A colorless oil. IR (neat): $3380,1640 \mathrm{~cm}^{-1} .{ }^{1} \mathrm{H}-\mathrm{NMR} \quad \delta: 5.97-5.79(2 \mathrm{H}, \mathrm{m}), 5.62(1 \mathrm{H}, \mathrm{d}$, $J=9.9 \mathrm{~Hz}), 5.16-5.08(2 \mathrm{H}, \mathrm{m}), 2.30(2 \mathrm{H}, \mathrm{d}, J=7.3 \mathrm{~Hz}), 2.10-1.88(2 \mathrm{H}$, $\mathrm{m}), 1.81-1.60(4 \mathrm{H}, \mathrm{m}) .{ }^{13} \mathrm{C}-\mathrm{NMR} \delta: 133.7$ (d), 132.1 (d), 130.2 (d), $118.6(\mathrm{t}), 69.2(\mathrm{~s}), 46.7(\mathrm{t}), 35.5(\mathrm{t}), 25.2(\mathrm{t}), 18.9(\mathrm{t})$.

3-Methyl-5-hexene-1,3-diol (3o) A colorless oil. IR (neat): 3360 , $1645 \mathrm{~cm}^{-1}$. ${ }^{1} \mathrm{H}-\mathrm{NMR} \delta: 6.01-5.85(1 \mathrm{H}, \mathrm{m}), 5.25-5.16(2 \mathrm{H}, \mathrm{m})$, $4.04-3.89(2 \mathrm{H}, \mathrm{m}), 2.77(2 \mathrm{H}, \mathrm{s}), 2.37(2 \mathrm{H}, \mathrm{d}, J=7.3 \mathrm{~Hz}), 1.93-1.71$ $(2 \mathrm{H}, \mathrm{m}), 1.32(3 \mathrm{H}, \mathrm{s}) .{ }^{13} \mathrm{C}-\mathrm{NMR} \delta: 133.6(\mathrm{~d}), 118.9(\mathrm{t}), 73.2(\mathrm{~s}), 59.7$ $(\mathrm{t}), 47.0(\mathrm{t}), 41.5(\mathrm{t}), 26.7(\mathrm{q})$.

Methyl 3-Hydroxy-3-methyl-5-hexenoate (3p) A colorless oil. IR (neat): $3500,1725,1640 \mathrm{~cm}^{-1}$. ${ }^{1} \mathrm{H}-\mathrm{NMR} \delta: 5.93-5.77(1 \mathrm{H}, \mathrm{m})$, $5.15-5.05(2 \mathrm{H}, \mathrm{m}), 3.72(3 \mathrm{H}, \mathrm{s}), 2.54(1 \mathrm{H}, \mathrm{d}, J=12.5 \mathrm{~Hz}), 2.43(1 \mathrm{H}, \mathrm{d}$, $J=12.5 \mathrm{~Hz}), 2.31(2 \mathrm{H}, \mathrm{d}, J=7.3 \mathrm{~Hz}), 1.25(3 \mathrm{H}, \mathrm{s}) .{ }^{13} \mathrm{C}-\mathrm{NMR} \delta: 173.3$ $(\mathrm{s}), 133.6(\mathrm{~d}), 118.6(\mathrm{t}), 70.6(\mathrm{~s}), 51.6(\mathrm{q}), 46.4(\mathrm{t}), 44.1(\mathrm{t}), 26.8(\mathrm{q})$. 
2,2-Dimethyl-1-phenyl-3-buten-1-ol (4a) A colorless oil. IR (neat): $3470,1640 \mathrm{~cm}^{-1} .{ }^{1} \mathrm{H}-\mathrm{NMR} \quad \delta: 7.30(5 \mathrm{H}, \mathrm{s}), 5.92(1 \mathrm{H}, \mathrm{dd}, J=17.5$, $10.6 \mathrm{~Hz}), 5.12(2 \mathrm{H}, \mathrm{m}), 4.43(1 \mathrm{H}, \mathrm{s}), 2.04(1 \mathrm{H}, \mathrm{br} \mathrm{s}), 1.01(3 \mathrm{H}, \mathrm{s}), 0.96$ (3H, s). ${ }^{13}$ C-NMR $\delta: 145.1$ (d), 140.7 (s), 127.8 (d), 127.5 (d), 127.4(d), $113.9(\mathrm{t}), 80.6$ (d), 42.2 (s), 24.5 (q), 21.0 (q).

4,4-Dimethyl-1-phenyl-5-hexen-1-ol (4b) A colorless oil. IR (neat): $3470,1640,1609 \mathrm{~cm}^{-1} .{ }^{1} \mathrm{H}-\mathrm{NMR} \delta: 7.32-7.18(5 \mathrm{H}, \mathrm{m}), 5.79(1 \mathrm{H}, \mathrm{dd}$, $J=17.5,10.9 \mathrm{~Hz}), 5.13-5.01(2 \mathrm{H}, \mathrm{m}), 3.28(1 \mathrm{H}, \mathrm{d}, J=10.6 \mathrm{~Hz})$, $2.98-2.87(1 \mathrm{H}, \mathrm{m}), 2.67-2.55(1 \mathrm{H}, \mathrm{m}), 1.89-1.77(1 \mathrm{H} . \mathrm{m}), 1.64-1.49$ $(1 \mathrm{H}, \mathrm{m}), 1.00(6 \mathrm{H}, \mathrm{s}) .{ }^{13} \mathrm{C}-\mathrm{NMR} \delta: 147.0(\mathrm{~d}), 129.3$ (d), 129.1 (d), 112.0 (t), $77.8(\mathrm{~d}), 42.0(\mathrm{~s}), 35.0(\mathrm{t}), 33.9(\mathrm{t}), 24.3(\mathrm{q}), 22.4(\mathrm{q})$.

1-Phenyl-1,2,2-trimethyl-3-buten-1-ol (4c) A colorless oil. IR (neat): $3500,1640,1607 \mathrm{~cm}^{-1} .{ }^{1} \mathrm{H}-\mathrm{NMR} \delta: 7.43-7.20(5 \mathrm{H}, \mathrm{m}), 5.95(1 \mathrm{H}, \mathrm{dd}$, $J=17.5,10.9 \mathrm{~Hz}), 5.13-5.02(2 \mathrm{H}, \mathrm{m}), 1.94(1 \mathrm{H}, \mathrm{br} \mathrm{s}), 1.57(3 \mathrm{H}, \mathrm{s}), 1.01$ $(3 \mathrm{H}, \mathrm{s}), 0.98(3 \mathrm{H}, \mathrm{s}) .{ }^{13} \mathrm{C}-\mathrm{NMR} \delta: 145.3$ (s), 145.1 (d), 127.1 (d), 127.0 (d), 126.4 (d), 113.8 (t), 44.3 (s), 25.3 (q), 22.7 (q), 22.4 (q).

1,4-Diphenyl-5-hexen-1-ol (4h) This was obtained as a mixture of diastereomers, which were separated by column chromatography $\left(\mathrm{SiO}_{2}-5 \% \mathrm{AgNO}_{3}\right.$, hexane-ethyl acetate). Erythro isomer: A colorless oil. IR (neat): $3570,3450,1640,1601 \mathrm{~cm}^{-1}{ }^{1} \mathrm{H}-\mathrm{NMR} \delta: 7.36-7.07$ $(10 \mathrm{H}, \mathrm{m}), 6.20-6.02(1 \mathrm{H}, \mathrm{m}), 5.25-5.16(2 \mathrm{H}, \mathrm{m}), 3.80(1 \mathrm{H}, \mathrm{dt}, J=7.5$, $4.4 \mathrm{~Hz}), 3.27(1 \mathrm{H}, \mathrm{dd}, J=9.0,7.5 \mathrm{~Hz}), 2.87-2.76(1 \mathrm{H}, \mathrm{m}), 2.69-2.54$ $(1 \mathrm{H}, \mathrm{m}), 1.79-1.62(2 \mathrm{H}, \mathrm{m}) .{ }^{13} \mathrm{C}-\mathrm{NMR} \delta: 142.0(\mathrm{~s}), 141.3(\mathrm{~s}), 138.2(\mathrm{~d})$, 128.8 (d), 128.7 (d), 128.4 (d), 128.3 (d), 127.9 (d), 126.7 (d), 125.7 (d), $118.0(\mathrm{t}), 73.1$ (d), $57.5(\mathrm{~d}), 36.0(\mathrm{t}), 32.0(\mathrm{t})$. Threo isomer: A colorless oil. IR (neat): $3540,3450,1645,1601 \mathrm{~cm}^{-1}$. ${ }^{1} \mathrm{H}-\mathrm{NMR} \delta: 7.41-7.12$ $(10 \mathrm{H}, \mathrm{m}), 6.11-5.92(1 \mathrm{H}, \mathrm{m}), 5.16-5.07(2 \mathrm{H}, \mathrm{m}), 3.93-3.84(1 \mathrm{H}, \mathrm{m})$, $3.33(1 \mathrm{H}, \mathrm{t}, J=8.1 \mathrm{~Hz}), 2.96-2.82(1 \mathrm{H}, \mathrm{m}), 2.75-2.60(1 \mathrm{H}, \mathrm{m})$, $2.05-1.89(1 \mathrm{H}, \mathrm{m}), 1.74-1.58(1 \mathrm{H}, \mathrm{m}), 1.51(1 \mathrm{H}, \mathrm{br} \mathrm{s}) .{ }^{13} \mathrm{C}-\mathrm{NMR} \delta$ : 142.2 (s), 140.7 (s), 138.3 (d), 128.8 (d), 128.7 (d), 128.5 (d), 128.4 (d), 127.0 (d), 125.8 (d), $117.0(\mathrm{t}), 73.5(\mathrm{~d}), 57.5(\mathrm{~d}), 36.3(\mathrm{t}), 32.1(\mathrm{t})$.

1,2-Diphenyl-1-methyl-3-buten-1-ol (4i) This was obtained as a mixture of diastereomers. A colorless oil. IR (neat): $3580,3480,1638$, $1601 \mathrm{~cm}^{-1}$. Erythro isomer, ${ }^{1} \mathrm{H}-\mathrm{NMR} \delta: 1.57(1 \mathrm{H}, \mathrm{brs}), 1.46(3 \mathrm{H}, \mathrm{s})$. ${ }^{13} \mathrm{C}-\mathrm{NMR} \delta: 76.2(\mathrm{~s}), 61.8$ (d), 28.5 (q). Threo isomer, ${ }^{1} \mathrm{H}-\mathrm{NMR} \delta: 2.02$ $(1 \mathrm{H}, \mathrm{brs}), 1.61(3 \mathrm{H}, \mathrm{s}) .{ }^{13} \mathrm{C}-\mathrm{NMR} \delta: 76.0(\mathrm{~s}), 62.2(\mathrm{~d}), 27.8$ (q).

2-Phenyl-4-hexen-2-ol (5i) A colorless oil. IR (neat): 3570, 3400, 1650, $1600 \mathrm{~cm}^{-1} .{ }^{1} \mathrm{H}-\mathrm{NMR} \delta: 7.50-7.22(10 \mathrm{H}, \mathrm{m}), 6.48(1 \mathrm{H}, \mathrm{dt}, J=15.9$, $1.2 \mathrm{~Hz}), 6.02(1 \mathrm{H}$, ddd, $J=15.9,8.4,6.6 \mathrm{~Hz}), 2.83(1 \mathrm{H}$, ddd, $J=13.5$, $6.6,1.2 \mathrm{~Hz}), 2.65(1 \mathrm{H}$, ddd, $J=13.5,8.4,1.2 \mathrm{~Hz}), 1.60(3 \mathrm{H}, \mathrm{s}) .{ }^{13} \mathrm{C}-\mathrm{NMR}$ $\delta: 147.9$ (s), 137.0 (d), 134.4 (d), 128.5 (d), 128.2 (d), 127.4 (d), 126.7 (d), 126.2 (d), 125.0 (d), 124.7 (d), 77.2 (s), 47.7 (t), 29.9 (q).

1-(2-Cyclohexen-1-yl)-3-phenylpropan-1-ol (4k) This was obtained as a mixture of diastereomers. A white powder. IR $\left(\mathrm{CHCl}_{3}\right): 3300$, $1602 \mathrm{~cm}^{-1}$. Erythro isomer, ${ }^{1} \mathrm{H}-\mathrm{NMR} \delta: 7.33-7.14(5 \mathrm{H}, \mathrm{m}), 5.91-5.81$ $(1 \mathrm{H}, \mathrm{m}), 5.71-5.65(1 \mathrm{H}, \mathrm{m}), 3.52-3.44(1 \mathrm{H}, \mathrm{m}), 2.74-2.59(2 \mathrm{H}, \mathrm{m})$, $2.29-2.18(1 \mathrm{H}, \mathrm{m}), 2.04-1.91(2 \mathrm{H}, \mathrm{m}), 1.88-1.67(4 \mathrm{H}, \mathrm{m}), 1.62-1.42$ $(2 \mathrm{H}, \mathrm{m}) .{ }^{13} \mathrm{C}-\mathrm{NMR} \delta: 142.2(\mathrm{~s}), 130.30$ (d), 128.4 (d), $126.6(\mathrm{~d}), 125.8$ (d), $74.7(\mathrm{~d}), 41.5(\mathrm{~d}), 36.4(\mathrm{t}), 32.4(\mathrm{t}), 25.2(\mathrm{t}), 22.7(\mathrm{t}), 21.7(\mathrm{t})$. Threo isomer, ${ }^{1} \mathrm{H}$-NMR $\delta: 5.57-5.28(1 \mathrm{H}, \mathrm{m}), 3.64-3.56(1 \mathrm{H}, \mathrm{m}), 2.93-2.78$ $(2 \mathrm{H}, \mathrm{m}) .{ }^{13} \mathrm{C}-\mathrm{NMR} \delta: 73.9(\mathrm{~d}), 35.6(\mathrm{t}), 32.5(\mathrm{t}), 25.8(\mathrm{t}), 21.4(\mathrm{t})$.

1-(2-Cyclohexen-1-yl)-1-phenylethanol (4l) This was obtained as a mixture of diastereomers. A colorless oil. IR (neat): 3410, 1655, $1608 \mathrm{~cm}^{-1}$. Erythro isomer, ${ }^{1} \mathrm{H}-\mathrm{NMR} \delta: 7.45-7.23(5 \mathrm{H}, \mathrm{m}), 5.96-5.87$ $(1 \mathrm{H}, \mathrm{m}), 5.81-5.74(1 \mathrm{H}, \mathrm{m}), 2.59-2.52(1 \mathrm{H}, \mathrm{m}), 1.97-1.90(2 \mathrm{H}, \mathrm{m})$, $1.79-\mathrm{i} .65(2 \mathrm{H}, \mathrm{m}), 1.60(3 \mathrm{H}, \mathrm{s}), 1.50-1.22(2 \mathrm{H}, \mathrm{m}) .{ }^{13} \mathrm{C}-\mathrm{NMR} \delta: 147.7$ (s), 132.0 (d), 128.4 (d), 127.1 (d), 126.9 (d), 125.8 (d), 76.6 (s), 47.1 (d), $28.3(\mathrm{q}), 25.7(\mathrm{t}), 24.9$ (t), $22.5(\mathrm{t})$. Threo isomer, ${ }^{13} \mathrm{C}-\mathrm{NMR} \delta: 76.8(\mathrm{~s})$, $46.9(\mathrm{~d}), 27.6(\mathrm{q}), 25.9(\mathrm{t}), 24.6(\mathrm{t}), 22.6(\mathrm{t})$.

General Procedure for the Runs in Table IV Allyl bromide (2a) $(4 \mathrm{mmol})$ was added to a suspension of $\mathrm{Zn}(4 \mathrm{mmol})$ and $\mathrm{AlCl}_{3}(4 \mathrm{mmol})$ in THF ( $3 \mathrm{ml}$ ), causing an exothermic reaction. Then, an acetal (6) $(2 \mathrm{mmol})$ was added. The resulting mixture was stirred until 6 was totally consumed. The same work-up procedure as used for the allylation of 1 was applied to give pure 7 . All products gave satisfactory IR, ${ }^{1} \mathrm{H}-\mathrm{NMR}$, and ${ }^{13} \mathrm{C}$-NMR spectra (see below).

1-Methoxy-1-phenyl-3-butene (7a) A colorless oil. IR (neat): 1648, $1608,1104 \mathrm{~cm}^{-1} .{ }^{1} \mathrm{H}-\mathrm{NMR} \delta: 7.37-7.24(5 \mathrm{H}, \mathrm{m}), 5.84-5.69(1 \mathrm{H}, \mathrm{m})$, $5.08-5.00(2 \mathrm{H}, \mathrm{m}), 4.16(1 \mathrm{H}, \mathrm{dd}, J=7.6,5.9 \mathrm{~Hz}), 3.22(3 \mathrm{H}, \mathrm{s}), 2.62-2.51$ $(1 \mathrm{H}, \mathrm{m}), 2.45-2.35(1 \mathrm{H}, \mathrm{m}) .{ }^{13} \mathrm{C}-\mathrm{NMR} \delta: 141.98(\mathrm{~s}), 135.11$ (d), 128.66 (d), 127.93 (d), 127.33 (d), 127.03 (d), 117.20 (t), 83.95 (d), 59.96 (q), $42.86(\mathrm{t})$.

3-Methoxy-1-phenyl-5-hexene (7b) A colorless oil. IR (neat): 1645, $1100 \mathrm{~cm}^{-1} .{ }^{1} \mathrm{H}-\mathrm{NMR} \quad \delta: 7.28-7.21(5 \mathrm{H}, \mathrm{m}), 5.89-5.73(1 \mathrm{H}, \mathrm{m})$, $5.12-5.05(2 \mathrm{H}, \mathrm{m}), 3.37(3 \mathrm{H}, \mathrm{s}), 3.25(1 \mathrm{H}, \mathrm{q}, J=5.9 \mathrm{~Hz}), 2.80-2.57$ $(2 \mathrm{H}, \mathrm{m}), 2.31(2 \mathrm{H}, \mathrm{t}, J=6.6 \mathrm{~Hz}), 1.84-1.75(2 \mathrm{H}, \mathrm{m}) .{ }^{13} \mathrm{C}-\mathrm{NMR} \delta: 134.6$ (d), 128.4 (d), 128.3 (d), 125.7 (d), 117.1 (t), 79.6 (d), $56.5(\mathrm{q}), 37.6(\mathrm{t})$, $35.3(\mathrm{t}), 31.5(\mathrm{t})$.

1-Cyclohexyl-1-methoxy-3-butene (7c) A colorless oil. IR (neat): $1640,1100 \mathrm{~cm}^{-1} .{ }^{1} \mathrm{H}-\mathrm{NMR} \delta: 5.93-5.77(1 \mathrm{H}, \mathrm{m}), 5.12-5.01(2 \mathrm{H}, \mathrm{m})$, $3.34(3 \mathrm{H}, \mathrm{s}), 2.94(1 \mathrm{H}, \mathrm{dd}, J=11.5,5.6 \mathrm{~Hz}), 2.33-2.19(2 \mathrm{H}, \mathrm{m})$ $1.82-0.96(11 \mathrm{H}, \mathrm{m}) .{ }^{13} \mathrm{C}-\mathrm{NMR} \delta: 135.6(\mathrm{~d}), 116.3(\mathrm{t}), 85.3(\mathrm{~d}), 57.7(\mathrm{q})$, $40.8(\mathrm{~d}), 34.9(\mathrm{t}), 28.8(\mathrm{t}), 28.5(\mathrm{t}), 26.6(\mathrm{t}), 26.4(\mathrm{t}), 26.3(\mathrm{t})$.

3-Methoxy-1-phenyl-1,5-hexadiene (7d) A colorless oil. IR (neat): $1640,1100 \mathrm{~cm}^{-1} .{ }^{1} \mathrm{H}-\mathrm{NMR} \quad \delta: 7.48-7.20(5 \mathrm{H}, \mathrm{m}), 6.55(1 \mathrm{H}, \mathrm{d}$ $J=15.8 \mathrm{~Hz}), 6.07(1 \mathrm{H}, \mathrm{dd}, J=15.8,7.8 \mathrm{~Hz}), 5.95-5.74(1 \mathrm{H}, \mathrm{m})$, 5.17-5.04 $(2 \mathrm{H}, \mathrm{m}), 3.83-3.73(1 \mathrm{H}, \mathrm{m}), 3.33(3 \mathrm{H}, \mathrm{s}), 2.47-2.32(2 \mathrm{H}$, m). ${ }^{13}$ C-NMR $\delta: 136.5$ (s), 134.4 (d), 132.5 (d), 130.0 (d), 128.6 (d), 127.7 (d), 126.5 (d), $117.1(\mathrm{t}), 82.0$ (d), $56.3(\mathrm{q}), 40.2(\mathrm{t})$.

3-Oxa-4-phenyl-6-hepten-1-ol (7e) A colorless oil. IR (neat): 3450, $1645 \mathrm{~cm}^{-1} .{ }^{1} \mathrm{H}-\mathrm{NMR} \quad \delta: 7.36-7.24(5 \mathrm{H}, \mathrm{m}), 5.81-5.72(1 \mathrm{H}, \mathrm{m})$, $5.12-5.01(2 \mathrm{H}, \mathrm{m}), 4.31(1 \mathrm{H}, \mathrm{dd}, J=7.7,5.7 \mathrm{~Hz}), 3.69(2 \mathrm{H}, \mathrm{t}, J=4.8 \mathrm{~Hz})$ $3.49-3.36(2 \mathrm{H}, \mathrm{m}), 2.60-2.42(2 \mathrm{H}, \mathrm{m}) .{ }^{13} \mathrm{C}-\mathrm{NMR} \delta: 142.2(\mathrm{~s}), 135.2$ (d), 128.9 (d), $128.2(\mathrm{~d}), 127.0(\mathrm{~d}), 117.6(\mathrm{t}), 82.8(\mathrm{~d}), 70.3(\mathrm{t}), 62.4(\mathrm{t})$, $43.0(\mathrm{t})$.

4-Oxa-5-phenyl-7-octen-1-ol (7f) A colorless oil. IR (neat): 3430, $1645 \mathrm{~cm}^{-1}$. ${ }^{1} \mathrm{H}-\mathrm{NMR} \delta: 7.39-7.26(5 \mathrm{H}, \mathrm{m}), 5.85-5.70(1 \mathrm{H}, \mathrm{m})$, $5.11-5.04(2 \mathrm{H}, \mathrm{m}), 4.28(1 \mathrm{H}, \mathrm{dd}, J=7.6,5.6 \mathrm{~Hz}), 3.77(2 \mathrm{H}, \mathrm{d}, J=5.6 \mathrm{~Hz})$, $3.57-3.41(2 \mathrm{H}, \mathrm{m}), 2.60-2.38(2 \mathrm{H}, \mathrm{m}), 2.36(1 \mathrm{H}, \mathrm{br} \mathrm{s}), 1.80(2 \mathrm{H}, \mathrm{q}$, $J=5.6 \mathrm{~Hz}) .{ }^{13} \mathrm{C}-\mathrm{NMR} \delta: 142.2$ (s), 134.6 (d), 128.4 (d), 127.7 (d), 126.6 $(\mathrm{d}), 117.3(\mathrm{t}), 82.4(\mathrm{~d}), 68.5(\mathrm{t}), 62.4(\mathrm{t}), 42.7(\mathrm{t}), 31.9(\mathrm{t})$.

\section{References}

1) a) C. Petrier, J. L. Luche, J. Org. Chem., 50, 910 (1985); b) C. Petrier, J. Einhorn, J. L. Luche, Tetrahedron Lett., 26, 1449 (1985); c) C. Einhorn, J. L. Luche, J. Organomet. Chem., 322, 177 (1987).

2) S. R. Wilson, M. E. Guazzaroni, J. Org. Chem., 54, 3087 (1989).

3) H. Maeda, J. Kawabata, H. Ohmori, Chem. Pharm. Bull., 40, 2834 (1992).

4) H. Waldmann, Synlett, 1990, 627.

5) M. Graudemar, Tetrahedron, 32, 1689 (1976).

6) Y. Yamamoto, K. Maruyama, J. Org. Chem., 48, 1565 (1983).

7) R. Noyori, I. Nishida, J. Sakata, J. Am. Chem. Soc., 103, 2106 (1981).

8) W. R. Roush, K. Ando, D. B. Powers, A. D. Palkowitz, R. L. Halterman, J. Am. Chem. Soc., 112, 6339 (1990).

9) D. Seebach, L. Widler, Helv. Chim. Acta, 65, 1972 (1982).

10) J. M. Coxon, G. W. Simpson, P. J. Steel, V. C. Trenerry, Aust. J. Chem., 37, 65 (1984).

11) K. Uneyama, H. Nanbu, S. Torii, Tetrahedron Lett., 27, 2395(1986).

12) D. Young, W. Kitching, Aust. J. Chem., 38, 1767 (1985).

13) R. W. Hoffmann, Angew. Chem. Int. Ed. Engl., 21, 555 (1982).

14) F. Barbot, P. Miginiac, J. Organomet. Chem., 170, 1 (1979); H. Ishikawa, T. Mukaiyama, S. Ikeda, Bull. Chem. Soc. Jpn., 54, 776 (1981) and references cited therein.

15) G. Molle, P. Bauer, J. Am. Chem. Soc., 104, 3481 (1982).

16) J. F. Ruppert, J. D. White, J. Org. Chem., 41, 550 (1976)

17) Y. Yamamoto, H. Yatagai, Y. Ishihara, N. Maeda, K. Maruyama, Tetrahedron, 40, 2239 (1987). 